\title{
Article \\ The Spread of the Soil-Borne Pathogen Fusarium solani in Stored Potato Can Be Controlled by Terrestrial Woodlice (Isopoda: Oniscidea)
}

\author{
Anett Mészárosné Póss ${ }^{1}$, Anikó Südiné Fehér ${ }^{2}$, Franciska Tóthné Bogdányi ${ }^{3} \mathbb{D}$ and Ferenc Tóth ${ }^{4,5, *}$ \\ 1 Institute of Geography and Geoinformatics, Faculty of Earth Science and Engineering, Miskolc University, \\ H-3515 Miskolc, Hungary; ecoanett@uni-miskolc.hu \\ 2 Doctoral School of Plant Sciences, Hungarian University of Agriculture and Life Sciences, Páter Károly u. 1., \\ H-2100 Gödöllő, Hungary; fehranik@gmail.com \\ 3 ImMuniPot Research Group, H-2100 Gödöllő, Hungary; t.bogdanyi.franciska@gmail.com \\ 4 Department of Zoology and Ecology, Institute for Wildlife Management and Nature Conservation, \\ Hungarian University of Agriculture and Life Sciences, Páter Károly u. 1., H-2100 Gödöllő, Hungary \\ 5 Hungarian Research Institute of Organic Agriculture (ÖMKi), Miklós tér 1., H-1033 Budapest, Hungary \\ * Correspondence: ferenc.toth@biokutatas.hu or toth.ferenc.vti@uni-mate.hu; Tel.: +36-30-555-1255
}

Citation: Mészárosné Póss, A.; Südiné Fehér, A.; Tóthné Bogdányi,

F.; Tóth, F. The Spread of the

Soil-Borne Pathogen Fusarium solani in Stored Potato Can Be Controlled by Terrestrial Woodlice (Isopoda: Oniscidea). Agriculture 2022, 12, 45. https://doi.org/10.3390/ agriculture12010045

Academic Editors: Alessandro Vitale, Rosario Paolo Mauro

and Ivana Castello

Received: 29 November 2021

Accepted: 28 December 2021

Published: 31 December 2021

Publisher's Note: MDPI stays neutral with regard to jurisdictional claims in published maps and institutional affiliations.

Copyright: (C) 2021 by the authors. Licensee MDPI, Basel, Switzerland. This article is an open access article distributed under the terms and conditions of the Creative Commons Attribution (CC BY) license (https:// creativecommons.org/licenses/by/ $4.0 /)$.

\begin{abstract}
Fusarium solani, a soil-borne pathogen of stored potato may be disseminated, and thus, the damage caused by the pathogen may be aggravated by the grazing activities of arthropods. To investigate whether terrestrial woodlice contribute to the spread or, instead, to the control of $F$. solani, we launched a series of pilot experiments. First, a laboratory feeding trial was set up to find whether and to what extent woodlice consume the mycelia of fungal pathogens, namely, Aspergillus niger, F. solani, Macrophomina phaseolina, and Sclerotinia sclerotiorum. This was followed by a second set of experiments to simulate storage conditions where potato tubers, either healthy or infected with $F$. solani, were offered to woodlice. We found that: (1) F. solani was accepted by woodlice but was not their most preferred food source; (2) the presence of woodlice reduced the spread of $F$. solani among potato tubers. Our results suggest that the classification of terrestrial woodlice as "storage pests" needs re-evaluation, as isopods have the potential to disinoculate infective plant remnants and, thus, reduce the spread of storage pathogens.
\end{abstract}

Keywords: ecosystem services; storage pest; disinoculation; disease control; food choice test; beneficial arthropods; Armadillidium vulgare; Porcellionides pruinosus; Porcellio scaber

\section{Introduction}

Potato (Solanum tuberosum L.) ranks fourth worldwide among the most important vegetables worldwide, only preceded by corn, rice, and wheat [1]. Post-harvest potato storage is burdened by soil-borne storage pathogens, among which Fusarium species are the most dangerous ones. Damage is always higher if more than one Fusarium species is involved. The spoilage involves the creation of dry spots, and although the oncoming symptoms may not appear at a visual check-up, they are even more serious. Among them are the reduction of starch and amylose content and the increase of sucrose and total soluble sugars [2]. In an artificial inoculation experiment, disease severity was found significantly different depending on Fusarium species and potato cultivars, but not on the methods of seed propagation [3]. Small-scale storage usually means storing the product grown on the neighboring land of the producer. This allows enjoying one's own products in the freshest conditions, as well as avoiding synthetic pesticides thus improving safety. One of the promising biological alternative methods is to apply chitosan in water with acetic acid. The effect on F. oxysporum, F. sambucinum, and F. graminearum was higher when the application took place before inoculation, rather than post-inoculation [4]. Moreover, a correlation was found recently between treating tubers with Bacillus subtilis strains and 
salicylic acid. Some of the tested combinations had a synergistic effect, and there was one combination whose effect outstandingly increased disease manifestation. Finding this synergy suggests another promising ecological alternative to Fusarium control [5]. The natural suppressivity of soils may also contribute to the natural control of Fusarium species. The most important prerequisites for suppressivity are that soil are covered (mulched), and their nutrient supply is adequate [6]. In a two-year study, where Fusarium-infected wheat straw was offered to various soil-dwelling arthropods, the quantity of fungal matter was significantly decreased in the faunistically enhanced mesocosms. This finding suggests not only that some arthropods do feed on fungal matter, regardless of its pathogenicity, but also that the reduction of the dispersal of fungal agents by feeding can be really effective [7].

Woodlice/isopods (Isopoda: Oniscidea) were found to feed on algae and fungal matter to obtain their polyunsaturated fatty acids [8]. In a semi-natural experimental setting, isopods massively feeding on fungi were able to control fungal communities [9]. Moreover, the genetic material of Aspergillus nidulans changed in relation to the grazing pressure by fungivorous macroarthropods including isopods [10]. The fact that fungi not only serve as a food for terrestrial isopods but also are preferred over bacterial material in a laboratory feeding experiment using the leaf litter of Alnus nepalensis [11] inspired us to conduct experiments with three isopods species to monitor their behavior and effect on the soil-borne pathogen Fusarium solani.

We monitored changes to fungal matter by recording the decrease and increase in the mycelia and documented the loss of tubers due to the feeding activities of isopods. Our aim was to monitor and possibly quantify the beneficial and/or harmful effect these three isopod species may have on stored potato by recording the loss of the mycelia of plant pathogens and the loss of tuber material due to feeding. We were also interested in evaluating the effect, if any at all, of isopods on the dissemination of a pathogenic agent in stored potato, observing the potential of isopods as potential biocontrol agents of fungal diseases.

\section{Materials and Methods}

\subsection{Tested Isopod Species and Fungal Pathogens}

2.1.1. Isopod Species

Armadillidium vulgare (Latreille)

The common pillbug is a small- to medium-sized isopod with body length of $12 \mathrm{~mm}$. The body is twice as long as it is wide. Most adults have a uniform, dark grey-colored body with motifs in pale shades of yellow, sometimes brown or red (in females). The margins of the patches are never white. Their pereopods are relatively short, and the telson has a distinctive trapezoid shape [12]. Often considered an invasive species [13,14], the common pillbug is a habitat generalist, one of the most frequent and abundant species of the genus. Its cuticle has a fine-grained surface, allowing for a wider tolerance of environmental conditions [15].

\section{Porcellio scaber (Latreille)}

The common rough woodlouse is a medium-sized isopod whose length ranges between 10 and $15 \mathrm{~mm}$. It has a uniform color in the shades of brown, grey, or orange. Males tend to be grey in their shades, while females and juveniles are more colorful. The motifs are pale, sometimes invisible. The epimera may be decorated with a line of spots along the sides. They do not have that smooth cuticle as many other Porcellio species and appear rough and coarse. The two pairs of lungs, distinctive to the Porcellio genus, appear as white patches on the abdominal side of the pleon. The common rough woodlouse is often found abundantly and flees when disturbed. It is common around settlements and in other habitats disturbed by human activities [12]. 


\section{Porcellioinides pruinosus (Brandt)}

The plum woodlouse is a medium-sized isopod whose length ranges between 8 and $12 \mathrm{~mm}$. Its color can be brownish, purple, or plum blue. The pale motifs are most visible on brown individuals [12]. The body is covered with a layer of microscopic bubbles, which gives the species its characteristic blue-gray bloom [16,17]. The pleon is wider than the pereion, so there is a split in the outline of the whole body where these parts meet. The widely distributed plum woodlouse flees when disturbed. It is of Mediterranean origin, synanthropic, common around humans worldwide, and prefers compost heaps and decomposing plant material [18].

\subsubsection{Tested Plant Pathogenic Fungi}

Fungi, except for Aspergillus niger, were obtained from the stock collection of the Entomology and Plant Pathogen Laboratory of the Department of Integrated Plant Protection of MATE, Hungarian University of Agricultural and Life Sciences (hereinafter: Laboratory).

Aspergillus niger Tieghem

The pathogen agent of the black mold that may be found on the surface of certain stored fruit belongs to the division Ascomycota, subdivision Pezizomycotina, class Eurotiomycetes, order Eurotiales, family Aspergillaceae, genus Aspergillus [19]. Although this fungus is responsible for economic loss related to various fruits and vegetables [20], it is also widely used to produce industrial compounds including citric acid, glucoamylase, and other enzymes [21]. The biological control of the Aspergillus niger black mold in onion may be accomplished by using antagonists of certain Penicillium species [20].

Fusarium solani (Martius) Saccardo

The foot or root rot pathogen belongs to the division Ascomycota, subdivision Pezizomycotina, class Sordariomycetes, order Hypocreales, family Nectriaceae, genus Fusarium [19]. F. solani may infect a wide range of plants of agricultural importance including members of the leguminous and solanaceous family, causing symptoms including wilting, chlorosis, or lesions [22]. For its biological control, growers may use crop rotation, soil improvement, resistant cultivars, and antagonistic bacterial agents [23].

\section{Macrophomina phaseolina (Tassi) Goidànich}

The pathogen that causes the disease described according to its symptoms as charcoal rot belongs to the division Ascomycota, class Dothideomycetes, order Botryosphaeriales, family Botryosphaeriaceae, genus Macrophomina [19]. The fungus poses a serious economic threat to soybean production and has a wide range of hosts including other pulses, corn, and sorghum, but certain fruit trees and forest trees can be hosts as well [24]. One of the recent ways for its biological control is based on breeding resistant soybean cultivars after the identification of genetic determinants of resistance to the disease [25].

\section{Sclerotinia sclerotiorum (Libert) de Bary}

White mold belongs to the division Ascomycota, subdivision Pezizomycotina, class Leotiomycetes, order Helotiales, family Sclerotiniaceae, genus Sclerotinia [19]. The disease it causes affects a spectrum of plant genera. Its most important hosts are members of composite, leguminous, or cruciferous families, most of them herbaceous [26,27]. The presence of white mold often coincides with optimal environmental conditions for maximum crop production; therefore, when loss occurs, it is usually serious [26]. Recent studies have found that bacterial agents may have the potential to combat the disease in rapeseed [28].

\subsection{Selection and Pre-Experimental Confinement Condition of Isopods}

Besides their simple availability and synanthropic lifestyle, $A$. vulgare, $P$. scaber, and $P$. pruinosus were selected as test species because they respond well to various environmental circumstances and are easy to rear in artificial conditions. Original specimens for woodlice 
culture were collected partly in a household compost pile (Monor, Pest county, Hungary) and partly at the Regional Waste Management Center (Pusztazámor, Pest county, Hungary) by handsorting and were identified using the taxonomic key of Farkas and Vilisics [12]. We made no difference between genders as this type of selection would have hurt the individuals, but gravid females were excluded. Before the experiment, animals were kept at $22-25^{\circ} \mathrm{C}$, following a $0-24 \mathrm{~h}$ light/dark regime in plastic containers at the Laboratory. For feeding, we used the same material they consumed at their location of collection: a mixed municipal green waste containing fallen leaves of maples, oak, planes, and fruit trees of local origin.

\subsection{Feeding Trial}

The experiment was conducted in the Laboratory, between 10 November and 6 December 2016. We used $40(4 \times 10: 10$ per treatment plus 10 control dishes) Petri dishes with a diameter of $8.5 \mathrm{~cm}$ in this experiment. Inocula of F. solani, M. phaseolina, and S. sclerotiorum were introduced separately into the Petri dishes. Fungal colonies were kept on a potato dextrose agar medium [29]. The PDA medium was prepared on the first day. To $1000 \mathrm{~mL}$ of water, we added the following ingredients: tomato juice solids $20.0 \mathrm{~g}$, enzymatic digest of casein $10.0 \mathrm{~g}$, peptonized milk $10.0 \mathrm{~g}$, agar $11.0 \mathrm{~g}$, chloramphenicol $25.0 \mathrm{mg}$, reaching the final $\mathrm{pH}$ of $5.6 \pm 0.2$ at $25^{\circ} \mathrm{C}$. The remaining 10 Petri dishes were left uninoculated to serve as controls, but since they appeared to have been naturally infected with $A$. niger before the feeding experiment began, we deviated from the original conception and used this fourth fungus as the fourth treatment and only the "fungus-only" as a control in this experiment. A week after inoculation, 10 P. pruinosus individuals per dishes (at an average body weight of $115.03 \mathrm{mg}$ per individual) were introduced into 7 Petri dishes per every fungal colony, making 7 repetitions per fungus. The remaining 3 Petri dishes per fungus served as a "fungus-only" control (Figure 1).

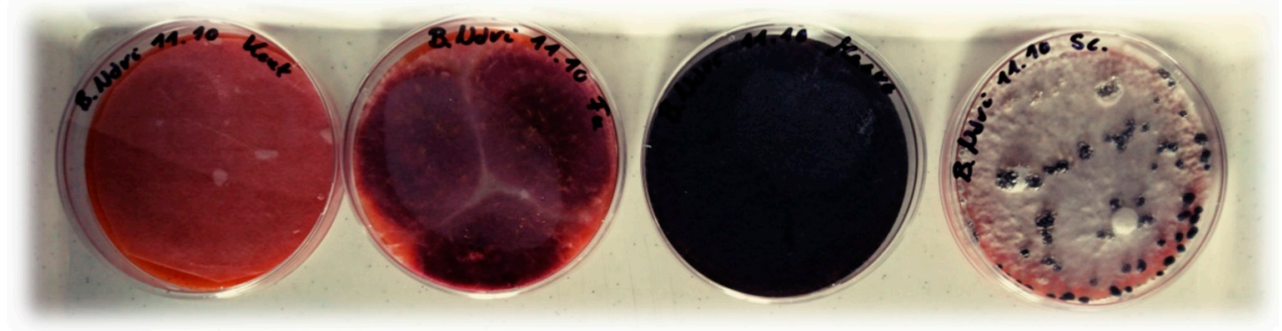

Figure 1. Food choice experiment to investigate different plant pathogen consumption of terrestrial isopods. From left to right, the image shows the pathogen-free control (later spontaneously infested by Aspergillus niger), followed by Petri dishes with Fusarium solani, Macrophomina phaseolina, and Sclerotinia sclerotiorum (Photo: Nóra Balázs, Gödöllő, Hungary, 2016).

Petri dishes were kept at a 0-24 h light/dark regime and placed randomly on a tray at $22-25^{\circ} \mathrm{C}$. We monitored the loss of mycelia and propagules of the different fungi (Figures 2-4) and recorded the number of isopod individuals to survey their mortality.

Samples were taken five times along the experiment (on 21, 24, 29 November and 02, 06 December). All Petri dishes were photographed throughout the experimental period according to the same setting (Resolution $5520 \times 4140$, $72 \mathrm{dpi}$, sRGB, 1/32s, ISO-100, focal length $4 \mathrm{~mm}$, no flash, Sony E5823), using the same station point. The diameter of the Petri dishes was uniformly $8.5 \mathrm{~cm}$. The print versions of these photographs were copied to a millimeter paper to quantify and evaluate the amount of mycelial loss. Initially, the computer programs AutoCAD, ImageJ, and some other software were also used for measurements but they were not reliable enough. Therefore, a manual but much more reliable method was chosen to quantify the results. AutoCAD is basically a design program that could have calculated the area consumed by woodlice, but did not give accurate results for some photograph and fungal species (Macrophomina phaseolina). Based on the AutoCAD program, the area of the consumed parts was calculated using graph paper, which also 
showed the amount of mushroom consumption. The images taken during the recordings were printed, and then the parts consumed by the isopods were redrawn using graph paper, while providing the appropriate light source (Figure 5). The amount of weight loss could be quantified in square millimeters.
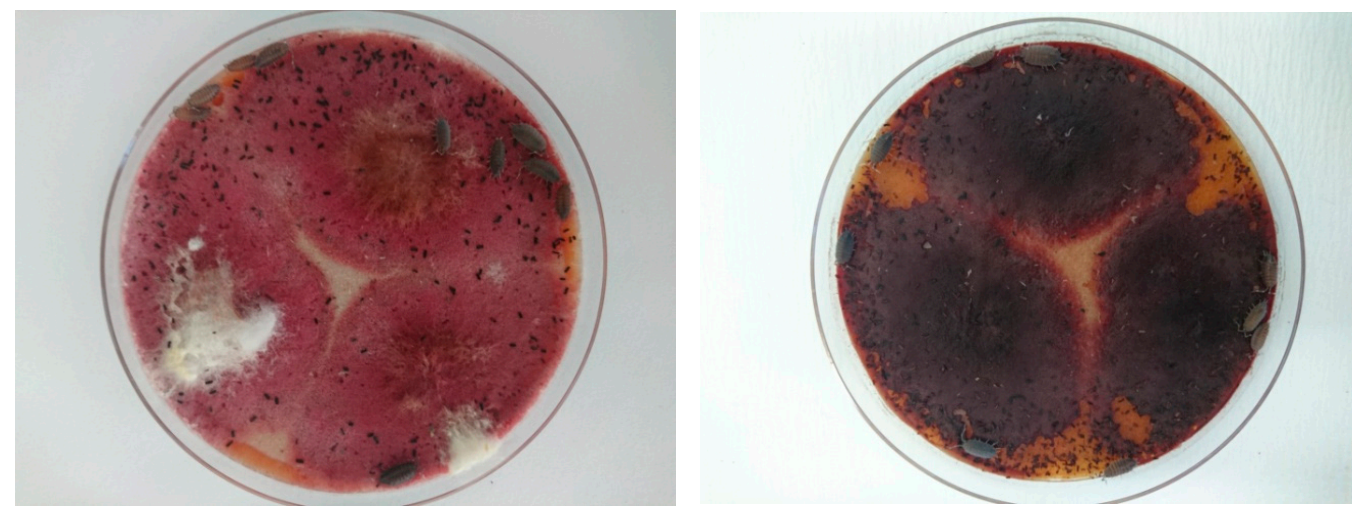

Figure 2. Fusarium solani mycelial loss in two weeks (Photo: Nóra Balázs, Gödöllő, Hungary, 2016).
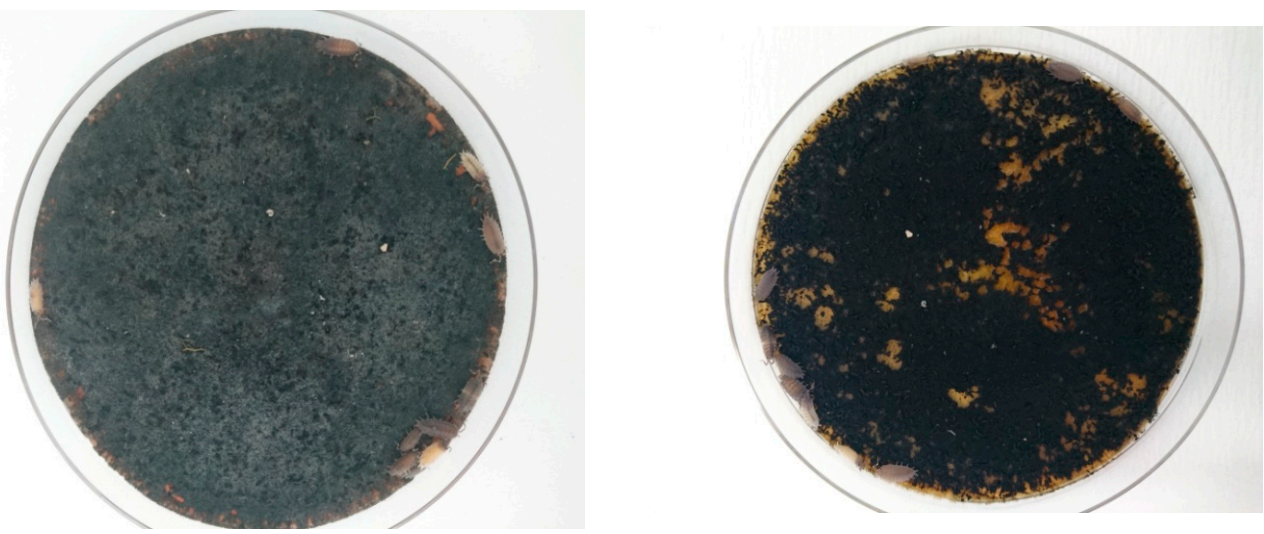

Figure 3. Machrophomina phaseolina mycelial loss in two weeks (Photo: Nóra Balázs, Gödöllő, Hungary, 2016).
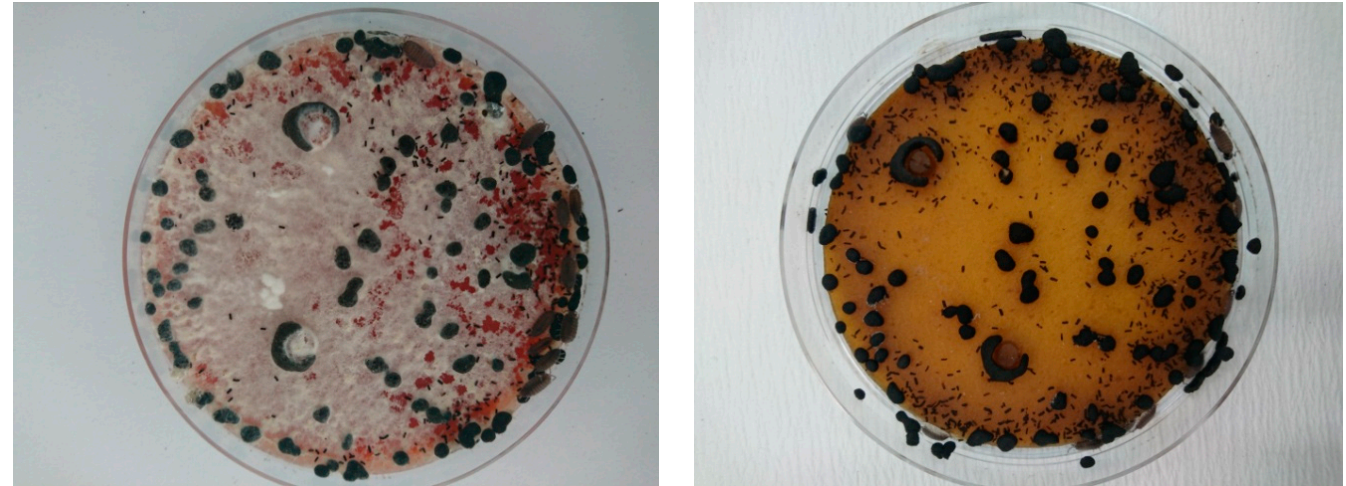

Figure 4. Sclerotinia sclerotiorum mycelial loss in two weeks (Photo: Nóra Balázs, Gödöllő, Hungary, 2016). 


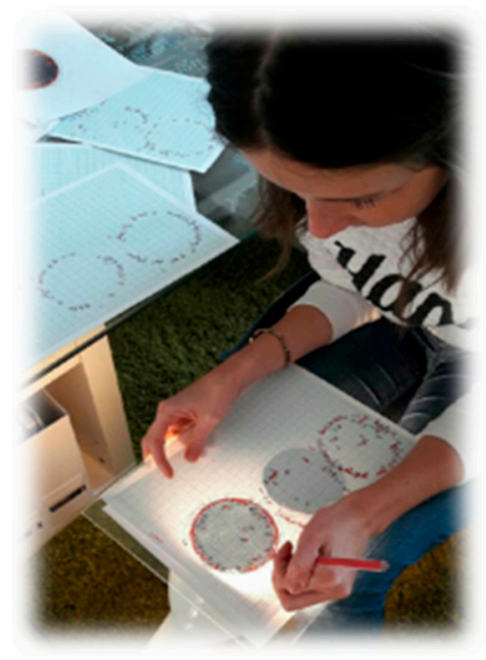

Figure 5. Evaluation of a food choice experiment with Porcellionides pruinosus studying the consumption of different pathogens at the Plant Protection Institute of the Hungarian University of Agriculture and Life Sciences (MATE) (Photo: Nóra Balázs, Hungary, Gödöllő, 2016).

\subsection{The Effect of Isopods on Fusarium Solani Infection of Stored Potato}

\subsubsection{Experiment A-Small boxes}

The experiment was conducted in the Laboratory, between 15 and 23 March 2017. We used 30 plastic boxes $(15 \times 11 \times 11 \mathrm{~cm}$ with lids $)$ with a slightly damp filter paper on the bottom to preserve moisture. F. solani was inoculated into a Petri dish on potato dextrose agar medium. Once the distinctive white mycelium appeared on the surface, $5 \mathrm{~mm}$-diameter discs were cut out of the agar to infect the tubers. For the experiment, we used 60 pieces of small, intact potato tubers with an average weight of $70.11 \mathrm{~g}$. We used two varieties in equal amount: the red-skin 'Balatoni Rózsa' and the yellow-skin 'Hópehely'. Thirty tubers were bruised with a lancet, and the agar discs with the mycelia were placed upon the fresh wounds. To prevent the mycelium from getting desiccated, each disc was secured to the tuber with a thin plastic wrap, which was discarded upon recognition of successful infection.

Two tubers of the same potato variety were placed into each box. One of the tubers was healthy, and the other one was inoculated. After the potatoes were inside the box, we introduced 5 individuals of $P$. scaber in each of the 10 boxes and 10 individuals of $P$. pruinosus in each of other 10 boxes. For $P$. scaber, we used half the number of individuals per box because the specimens of this species are larger and twice as heavy as those of the second species. The remaining 10 boxes were control boxes, containing only potatoes. After the setup, the boxes were covered $(\mathrm{L} / \mathrm{D}=0-24)$ and placed randomly at $22-25^{\circ} \mathrm{C}$. The mortality of isopods, the development and spread of the fungus, and the loss of fungal and potato matter due to the feeding of the isopods were recorded every other day for 10 days. The loss of potato was calculated by multiplying the diameter of the holes in the tubers by their depth. We generated a subjective scale to estimate the status of fungal infection, where 0 indicated visually Fusarium-free tubers, while 5 indicated the presence of the most severe symptoms (Figure 6).

\subsubsection{Experiment $\mathrm{B}$-Large Boxes}

The experiment started on 18 February 2018 and was closed on 17 May 2018. To simulate the general household storage conditions of potato, the experiment was conducted in three cellars in Gödöllő, Makó, and Neszmély between 18 February and 9 May (Gödöllő) and 17 May (Makó, Neszmély). In every location, there were 10 plastic boxes measuring $28 \times 38 \times 20 \mathrm{~cm}$. The bottom $5 \mathrm{~cm}$ layer of the boxes was filled with sand. We used the red-skin 'Demon' potato variety. To induce artificial infection on healthy potato, holes were bore into 10 tubers with a puncher. Into these holes, we placed discs cut out from 
clean colonies of F. solani. All utensils and surfaces were disinfected between actions. Infected tubers were individually wrapped into cling film after artificial inoculation and before the beginning of the experiment to ensure peri-optimal conditions for the pathogenic agent. We arranged 10 small healthy tubers (diameter, approximately $5 \mathrm{~cm}$ ) in the middle of the box. Then, with spatial separation, we placed the infected tuber at one end of the box, making sure that it had no contact with the healthy tubers in the middle. Temperature and relative humidity were approximately similar and steady in all locations, being about 5-11 ${ }^{\circ} \mathrm{C}$, and $60-80 \%$, respectively. All cellars had a natural light regime, which, given the local climate, equaled a 9-13 h light/dark period per day. Ten individuals of $A$. vulgare with an average body weight of $0.110 \mathrm{~g}$ were introduced into 5 of the boxes, and the remaining 5 boxes served as a control. In the boxes containing isopods, we introduced two oak leaves with a length of 6-8 $\mathrm{cm}$ as alternative feed, which were replenished when consumed during the experiment. The bottom layer of sand was monitored every two weeks for moisture content, and additional moisture was provided according to need by spraying two short shots of water with a hand sprayer. We recorded the number of isopods per box and the spread of F. solani. Damaged tubers with visible signs of chewing were separately collected, and the size of the chew marks were measured in cubic mm. From every box, tubers showing signs of Fusarium infection were also collected (Figure 7).

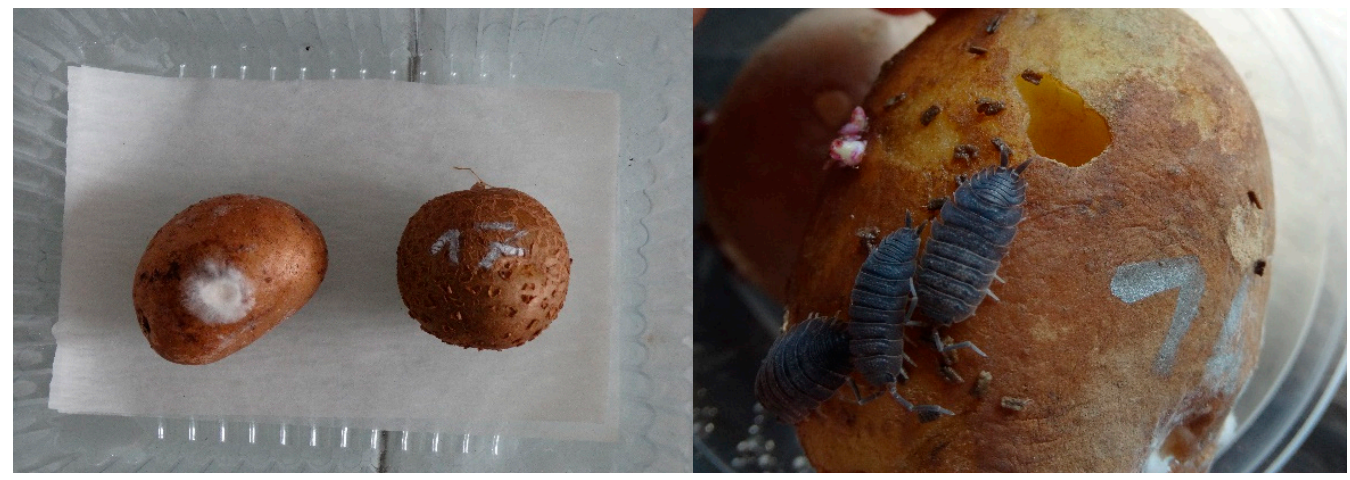

Figure 6. Experimental setup with small boxes: the effect of Porcellionides pruinosus on Fusarium solani infection of stored potato (Anikó Südiné Fehér, Gödöllő, Hun-gary, 2017).

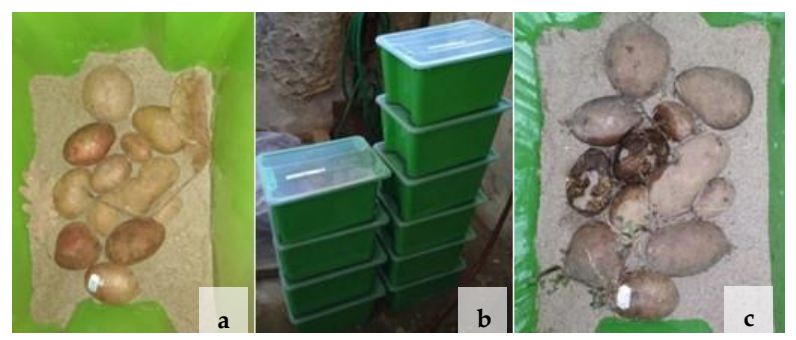

Figure 7. Experimental setup with large boxes to investigate the role of Armadillidium vulgare on Fusarium solani infection of stored potato in Gödöllő, Hungary 2018. (a) Tubers in a box at the beginning of the experiment. (b) Arrangement of boxes in one of the three involved storage cellars. (c) Tubers in a box at the termination of the experiment. The artificially in-fected tuber is marked with white. A. vulgare individuals were introduced to every sec-ond box. (Photo: Nóra Plangár).

\subsection{Identification of the Fungal Agent of Secondary Tuber Infections}

To select, isolate, and propagate the pathogen, we prepared a Fusarium-selective medium. (We boiled $1000 \mathrm{~mL}$ of water for $40 \mathrm{~min}$ in a pressure cooker with $15 \mathrm{~g}$ peptone adding $1 \mathrm{~g} \mathrm{KH} 2 \mathrm{PO} 4,0.5 \mathrm{~g} \mathrm{MgSO} 4$, and $20 \mathrm{~g}$ of agar. After cooking, we added $5 \mathrm{~mL}$ pentachloronitrobenzene (PCNB) and $10 \mathrm{~mL}$ chloramphenicol. The medium was then poured into Petri dishes in a sterile box). We allowed the fungal bodies to grow, and a week later, mycelial growth that resembled F. solani (thick formations of cells showing a 
white-pink coloration [30] were scraped and placed into a potato selective medium (500 $\mathrm{mL}$ water, $10 \mathrm{~g}$ potato powder, $10 \mathrm{~g}$ glucose, $8 \mathrm{~g}$ agar were heated for $30 \mathrm{~min}$ after the boiling point. Then, we added $5 \mathrm{~mL}$ chloramphenicol, and the medium was poured into Petri dishes in a sterile box). The transferred colonies were put under UV light for 4-5 days until conidia appeared, for a final determination based on the macroconidia of the pathogen [31].

\subsection{Statistical Analysis}

Data were evaluated using one-way AVOVA with Tukey's pairwise comparisons or Kruskal-Wallis test with Mann-Whitney pairwise comparisons. Data were analyzed with PAST $^{\circledR}$ statistical software [32].

\section{Results}

\subsection{Consumption of Fungal Pathogens on A Culture Medium}

The most intense mycelial loss was recorded in Petri dishes containing $S$. sclerotiorum, while $A$. niger was found to be the least favorite fungus among the four in our experiment during all the sampling times. The loss of fungal material due to the feeding activities of isopods was similar in M. phaseolina and F. solani: at the beginning, the loss of M. phaseolina was higher than that of F. solani, but the difference was not significant, and by the end of the experiment the loss to the two fungi was rather similar. Sclerotinia sclerotiorum was so heavily consumed that once the mycelia were completely ingested, the isopods started to feed upon the resting bodies (sclerotia) of the fungi. Consecutive samplings always showed a significant difference between the loss of fungal bodies of $S$. sclerotiorum and those of M. phaseolina, F. solani, or A. niger. The ingestion of propagules and mycelia of the most preferred fungus increased with time, so the difference between the loss of fungal bodies of S. sclerotiorum and those of the other fungi increased too. A. niger proved to be the least preferred fungus, practically ignored by isopod individuals (Figure 8). The lowest level of isopod mortality was recorded on M. phaseolina cultures (Figure 9).

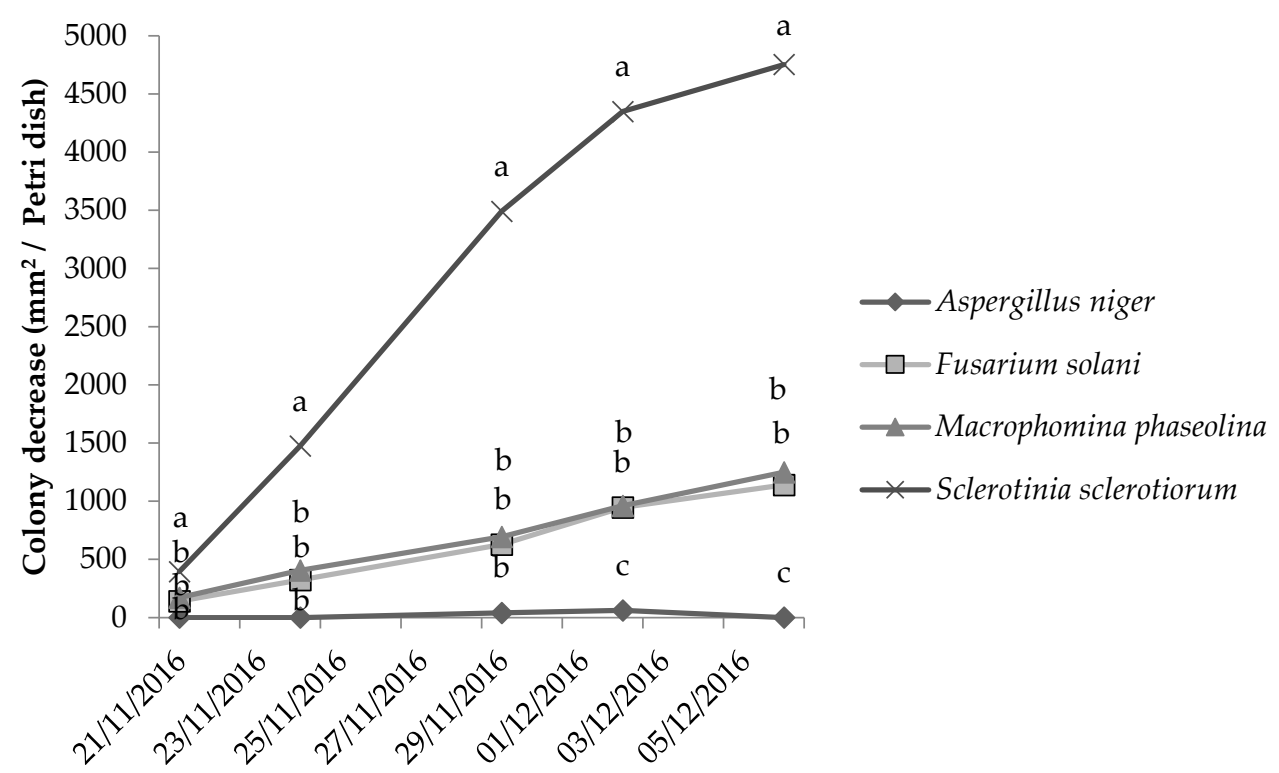

Figure 8. Average loss of mycelium in a feeding experiment where Porcellionides pruinosus individuals were offered four different fungi in Petri dishes. Different letters for the same sampling date indicate significant differences (ANOVA, Tukey's post hoc test). 


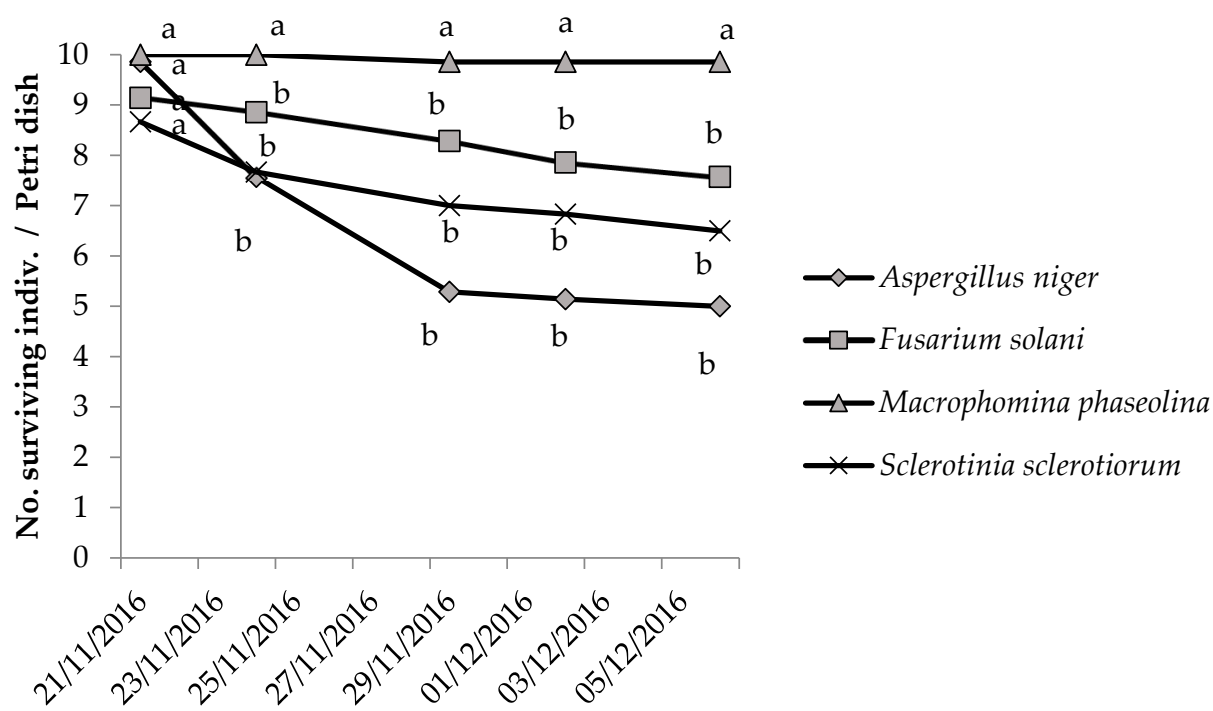

Figure 9. Number of surviving Porcellionides pruinosus individuals kept on different mycelial diets in Petri dishes. The initial number of individuals was 10 per Petri dish. Different letters for the same sampling date indicate significant differences (ANOVA, Tukey's post hoc test).

\subsection{Effect of Isopods on Fusarium Solani Infection of Stored Potato}

\subsubsection{Experiment A-Small Boxes}

The isopods left 6 of the $2^{\prime}$ originally healthy (not infected) tubers intact, but of the originally infected tubers, only 3 were left unharmed. Porcellio scaber individuals consumed significantly (10 times) more tuber material of the originally infected tubers during the experiment than individuals of P. pruinosus (Figure 10). When compared to the control, the infection rate due to $F$. solani was significantly lower in tubers originally infected with the pathogen. Figures for originally intact tubers, however, showed a significant difference only in the case of $P$. scaber, as there was no significant reduction in the spread of infection on tubers in boxes with P. pruinosus (Figure 11).

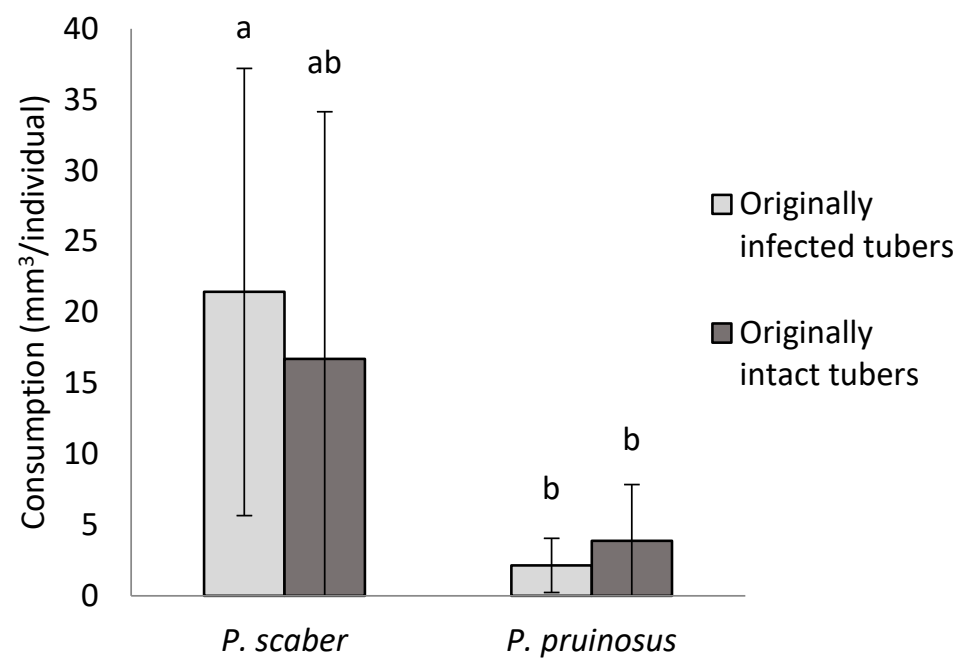

Figure 10. Difference between the consumption of infected and intact potato tubers by two isopod species (Porcellio scaber, Porcellionides pruinosus) in a feeding experiment where the animals were offered healthy and infected tubers (the same letters above the bars indicate the lack of a significant $(p \leq 0.05)$ difference according to the Kruskal-Wallis test with Mann-Whitney pairwise comparisons, uncorrected significance; error bar: CI 95\%). 


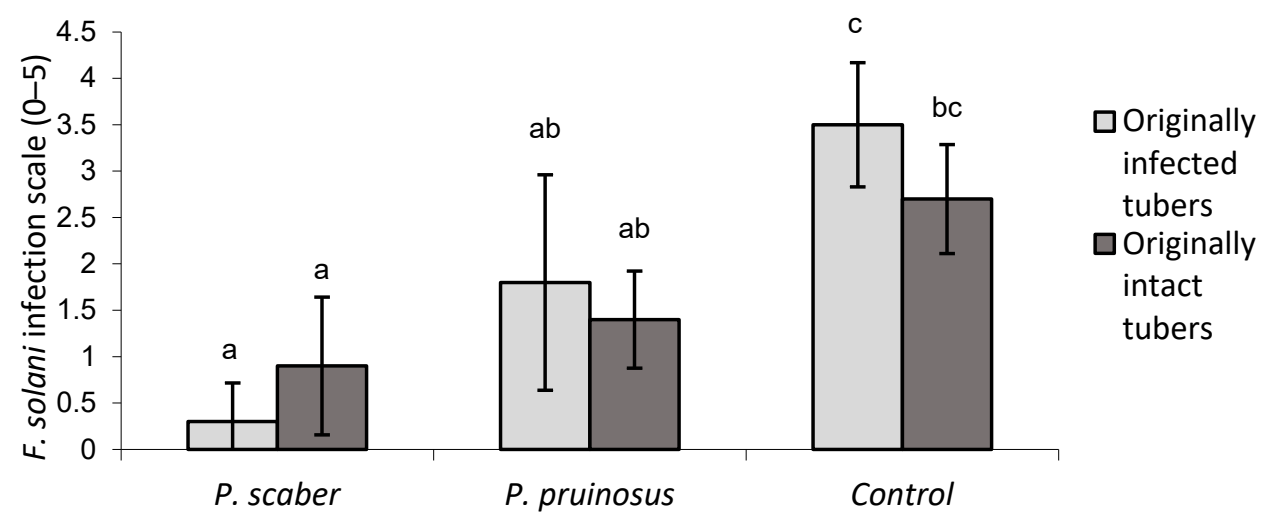

Figure 11. Effect of two isopod species (Porcellio scaber, Porcellionides pruinosus) on the spread of Fusarium solani on infected and on originally intact potato tubers (the same letters above the bars indicate the lack of a significant $(p \leq 0.05)$ difference according to ANOVA with Tukey's pairwise comparisons; error bar: CI 95\%).

\subsubsection{Experiment B-Large Boxes}

The ratio of infected tubers was higher in boxes without isopods. The average number of potentially infected tubers within the boxes with isopods was around 1.5, whereas in the absence of isopods, the number was as high as 3 (Figure 12). Microscopic evaluation of the seemingly infected tubers confirmed the presence of $F$. solani. The number of Fusariuminfected tubers in the boxes without isopods was high, reaching 2 in this treatment, whereas in boxes with isopods this figure was only 1.2 (Figure 13). There was a strong correlation between the results obtained by examinations taken by the naked eye and those obtained by microscopic evaluation (Spearman's $\mathrm{R}=0.83 ; p=2 \times 10^{-8}$ ). Both examinations had the same results: the number of infected tubers was lower in the boxes with isopods, although not significantly in most cases.

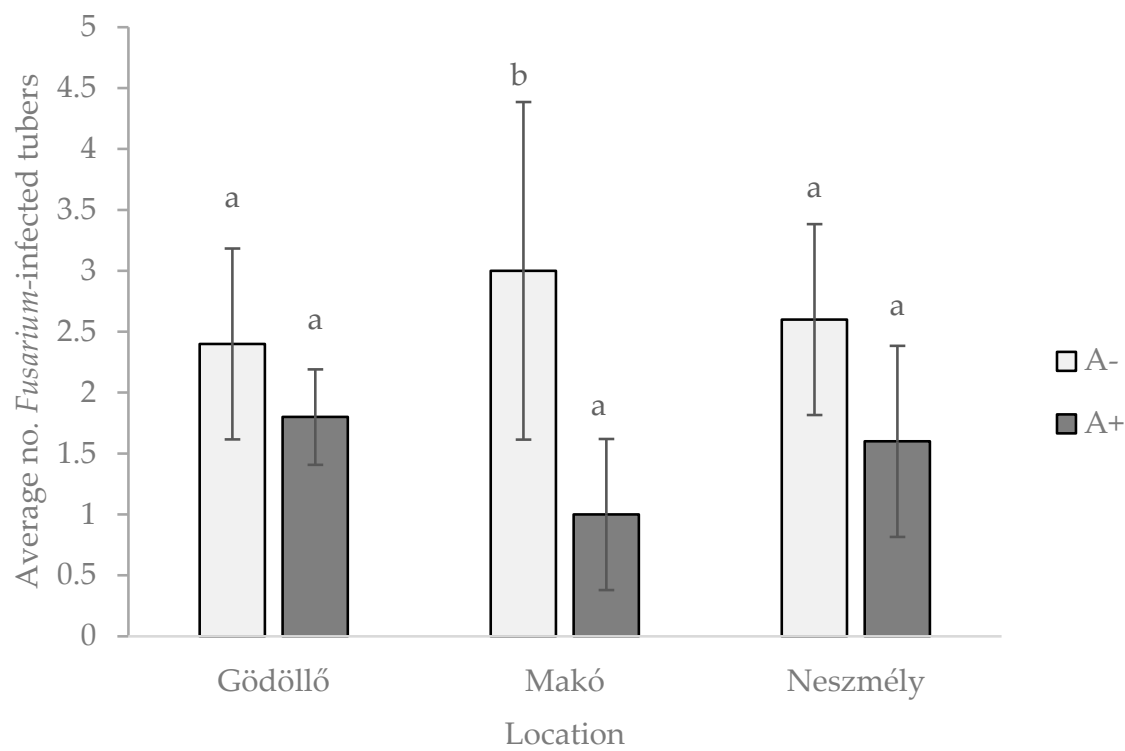

Figure 12. Effect of the presence of Armadillidium vulgare $(\mathrm{A}+)$ on the number of infected tubers in three locations (Gödöllő, Makó, Neszmély) in 2018, as determined by the naked eye. Different letters above the bars indicate a significant $(p \leq 0.05)$ difference between two treatments according to ANOVA and Tukey's pairwise comparisons; error bar: CI 95\%. 


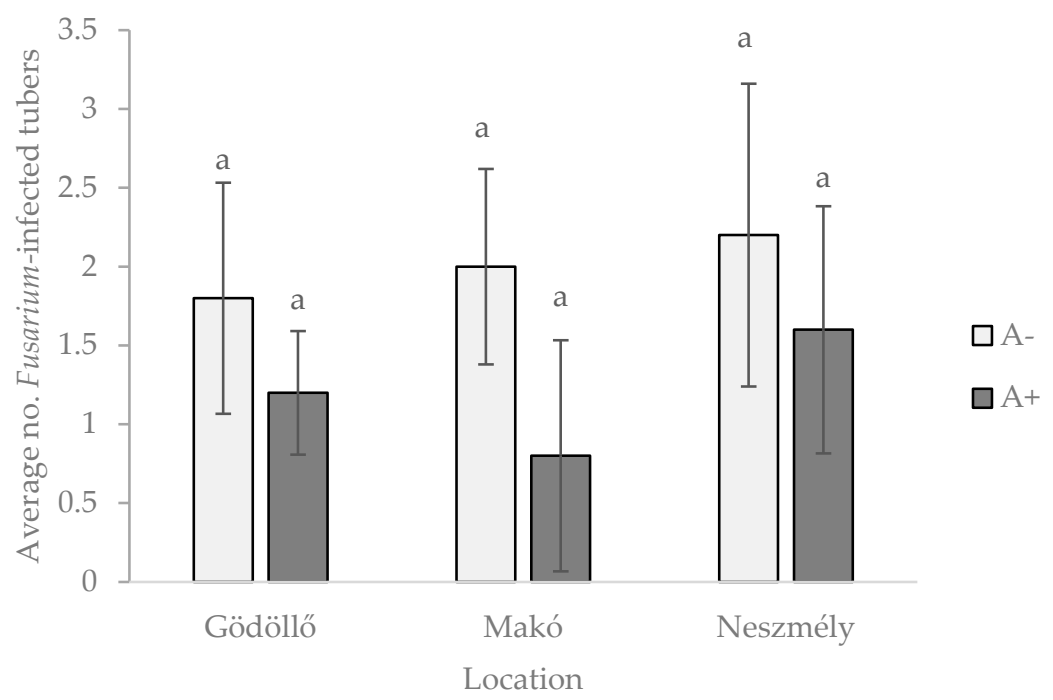

Figure 13. Effect of the presence of Armadillidium vulgare $(\mathrm{A}+)$ on the number of infected tubers in three locations (Gödöllő, Makó, Neszmély) in 2018 as confirmed by a microscopic evaluation. Different letters above the bars indicate a significant $(p \leq 0.05)$ difference between two treatments according to ANOVA and Tukey's pairwise comparisons; error bar: CI 95\%.

\section{Discussion}

The natural control of pests was recognized as a major ecosystem service about a decade and a half ago in a comprehensive work on major ecosystem services and disservices [33]. By 2010, the term 'pest' meant arthropods and small mammals, rodents in particular, although the interpretation of the taxa performing their control widely ranged from bacteria and viruses to predators, both invertebrate and vertebrate [34]. The consumption of pathogenic agents, however, was rather understudied in academic papers, as demonstrated in 2014 by a meta-analytical study [35]. According to this analysis, on the basis of the number of papers, studies investigating the consumption of plant pathogens and herbivores ranked only third in a list containing four types of papers on trophic effects. Later on, a distinction was made between direct pathogen consumption and indirect consumption of pathogens via consuming decaying material, where pathogens may rest in dormancy [36].

Before that, it was necessary to document whether isopods consumed the fungal bodies of pathogens. Isopods (members of the genus Oniscus, in particular) were proven to consume fungal bodies of arbuscular mycorrhizae [37]. Regarding the type of food offered, one of our basic aims was to test whether P. pruinosus, P. scaber, and A. vulgare consume fungal pathogens.

Prior to the start of the feeding trials, we assumed that, regardless of the short testing time, isopods would consume anything offered to them. In a cave study, isopods were expected to devour any organic matter available because of the limited food source [38]. Species that became specialized regardless of the harsh environment were found. This implied that there would be a similar specialization among isopod species regarding the consumption of plant pathogens.

This study showed that our tested isopod species consumed the mycelia and propagules of F. solani, M. phaseolina, and S. sclerotiorum. In another set of experiments, we also found that Gymnosporangium sabinae and Mycosphaerella pyri were also accepted as food by isopods [39].

Regarding any preference between different fungal species, the results revealed a general trend: there was always a significant difference between the loss of propagules and mycelia of S. sclerotiorum and those of M. phaseolina and F. solani or A. niger. The reason behind preferences was tackled by Zimmer [40], but knowledge of the sensory capabilities of isopods was limited. In one of our previous studies, we observed that P. pruinosus 
individuals preferred slices of carrots inoculated with B. bassiana and M. anisopliae over control, non-treated slices [41]. Food preference was reported by various studies [40,42-44] where leaves were fed to isopod species. To Ihnen and Zimmer [42], it became clear that $P$. scaber preferred easily digestible microbial agents. El-Wakeil [44] recorded different consumption and digestion ratios for the different food types. While P. pruinosus consumed the fungal mass of $S$. sclerotiorum in the highest amount, including the resting bodies, there was a definite hesitance in feeding when only A. niger was offered.

Moreover, survival rates substantially dropped, and reproduction halted completely in the presence of $A$. niger, and this might be the effect of Ochratoxin A, a mycotoxin produced by the fungus [45]. Our observations correspond to those of an earlier study [46], where juveniles were speculated to be more susceptible to changes in diet or to alterations to the nutrient content of available food. Although we took no measures regarding the toxin production of M. phaseolina [47], it did not seem to have any effect on the isopods in our experiment, as the diet of this plant pathogenic fungi brought about the highest survival rates and the highest number of individuals. Similarly, while the toxins of S. sclerotiorum were clearly detected [48], no information was available on their effect on isopods, and as in our experiments, not only the number of isopods seemed to rise, but also the number of juveniles peaked in the presence of $S$. sclerotiorum, rendering the fungus a valuable source of nutrition for P. pruinosus. We observed similar figures with $F$. solani; therefore, neither of the two fungi has any adverse effect on isopods. Whether the toxins have no actual influence on this isopod species, or whether it can tolerate high amounts of toxins remains unknown. Our findings confirm an earlier observation that the success of reproduction and the survival rate of isopods depended on the type of food consumed [46].

Our investigation of the effect of isopods on Fusarium solani infection of stored potato was based on the fact that, being saprophytic organisms, terrestrial isopods take part in material decomposition by grazing upon surfaces [49].

The main objective of our boxed experiments was to record the effect of isopods on the manifestation of a disease. Both micro-studies proved that the infection of potato tubers by F. solani was lower in containers with isopods, regardless of the species present. Armadillidium vulgare, P. scaber, and P. pruinosus were all able to significantly reduce the spread of $F$. solani by feeding on fungal bodies and infected plant tissues. In fact, these tested isopod species consumed more of the infected tubers than of the healthy ones. In the small-box experiment, the efficacy of the tested species in reducing the spread of the fungal disease was so high that Fusarium infection was halted. We also demonstrated that the feeding behavior of the two species in the small-box experiment was different: $P$. scaber was more capable of reducing infection than P. pruinosus when the tubers were originally healthy. During the fortnightly routine check in the big-box experiment, we often observed isopods deeply within a tuber exactly at the point of the artificial inoculation. These animals consumed the parts of the tuber that were inoculated with one of the pathogenic agents. Our tested isopods were able to modify the fungal diversity within the boxes by reducing the colonies of the dominant fungus. This finding is similar to that of an earlier study [9], where isopods increased the diversity of the surrounding fungus litter simply by allowing other, non-dominant species to thrive. Increasing the diversity of the soil microbiota increases its functional diversity and that improves soil suppressivity [50-53].

Our experiments proved the consumption of pathogens by isopods, but the overall positive appreciation of isopods in this situation may be threatened by the role of their feces in the dissemination. This issue has not been investigated thoroughly. The dispersal of two slime mold fungi, Dyctiostelium purpureum and Polysphondylium violaceum, was recorded by finding propagules in the isopod feces [54], and now we recorded that isopods do consume plant pathogens to the extent that they may actually control a fungal disease.

\section{Conclusions}

We believe this paper is the first to examine the effect isopod species may have on the survival and dissemination of $F$. solani in stored potato. The consumption of propagules and 
resting bodies of plant pathogens and egg masses of root-knot nematodes is an ecosystem service of high importance, yet it is hardly appreciated [55]. Our study suggests that besides antagonistic microorganisms, soil-dwelling invertebrates like terrestrial isopods, by the consumption of pathogens, also have a vital part in this ecosystem service. According to our results, isopods not only do not spread the disease, but also have the potential to stop its spreading. Our tests proved that P. pruinosus, P. scaber, and A. vulgare consume plant pathogens, and under certain circumstances, this consumption might be able to slow down or even halt the spread of infections. Our findings raise the need to perform further studies of this valuable ecosystem service provided by isopods under realistic production and storage conditions.

We may even assume that isopods may carry around beneficial antagonistic microorganisms with their grazing activities. Our experiments were set up to mimic small-scale storage conditions, and our results allow drawing conclusions at a small-scale level, for households and small farms. Their agronomic implications may include the creation and maintenance of isopod-supportive circumstances, such as adding a significant amount of leaf litter to storage rooms, that is, storing potatoes among leaf litter, being careful during regular check-ups, maintaining as little light in the storage room as possible.

Author Contributions: Conceptualization, F.T., A.M.P. and F.T.B.; Methodology, F.T., A.M.P. and A.S.F.; Software, F.T.; Validation, F.T.; Formal Analysis, F.T.; Investigation, A.M.P. and A.S.F.; Resources, A.M.P., A.S.F. and F.T.; Data Curation, F.T.; Writing-Original Draft Preparation, F.T.B.; Writing-Review \& Editing, A.M.P., A.S.F., F.T.B. and F.T.; Visualization, F.T.; Supervision, F.T.B. and F.T.; Project Administration, F.T.; Funding Acquisition, A.M.P., A.S.F. and F.T. All authors have read and agreed to the published version of the manuscript.

Funding: This work was supported by the New National Excellence Program (ÚNKP-19-4) of the Ministry of Human Capacities, Hungary.

Institutional Review Board Statement: Ethical review and approval were waived for this study due to the reason that the involved animals were invertebrates, and the experiments were short-term feeding experiments. These experiments do not require special approval in Hungary.

Informed Consent Statement: Not applicable.

Acknowledgments: The authors appreciate the work of Nóra Balázs and Nóra Plangár during laboratory experiments and are thankful for dr. György Turóczi, who contributed to the experiments by providing and identifying the tested plant pathogens. We appreciate Zoltánné Lénárt for her laboratory assistance and are thankful to Ilona Tündér Szőcs for her practical help in the preparation of the media and the inoculation of the fungi.

Conflicts of Interest: The authors declare no conflict of interest.

\section{References}

1. Harris, P.M. Mineral nutrition. In The Potato Crop: The Scientific Basis for Improvement, 2nd ed.; Harris, P.M., Ed.; Chapman \& Hall: London, UK, 1992; pp. 163-213.

2. Tiwari, R.K.; Bashyal, B.M.; Shanmugam, V.; Lal, M.K.; Kumar, R.; Sharma, S.; Gaikwad, V.K.; Singh, B.; Aggarwal, R. Impact of Fusarium dry rot on physicochemical attributes of potato tubers during postharvest storage. Postharvest Biol. Technol. 2021, 181, 111638. [CrossRef]

3. Platt, H.W. Cultivar response to Fusarium storage rot as affected by two methods of seed origin propagation; Clonal selection andin vitro culture. Am. J. Potato Res. 1992, 69, 179-186. [CrossRef]

4. Mejdoub-Trabelsi, B.; Touihri, S.; Ammar, N.; Riahi, A.; Daami-Remadi, M. Effect of chitosan for the control of potato diseases caused by Fusarium species. J. Phytopathol. 2020, 168, 18-27. [CrossRef]

5. Lastochkina, O.; Pusenkova, L.; Garshina, D.; Yuldashev, R.; Shpirnaya, I.; Kasnak, C.; Palamutoglu, R.; Mardanshin, I.; Garipova, S.; Sobhani, M.; et al. The Effect of Endophytic Bacteria Bacillus subtilis and Salicylic Acid on Some Resistance and Quality Traits of Stored Solanum tuberosum L. Tubers Infected with Fusarium Dry Rot. Plants 2020, 9, 738. [CrossRef] [PubMed]

6. Löbmann, M.T.; Vetukuri, R.R.; de Zinger, L.; Alsanius, B.W.; Grenville-Briggs, L.J.; Walter, A.J. The occurrence of pathogen suppressive soils in Sweden in relation to soil biota, soil properties, and farming practices. Appl. Soil Ecol. 2016, 107, 57-65. [CrossRef]

7. Meyer-Wolfarth, F.; Schrader, S.; Oldenburg, E.; Weinert, J.; Brunotte, J. Biocontrol of the toxigenic plant pathogen Fusarium culmorum by soil fauna in an agroecosystem. Mycotoxin Res. 2017, 33, 237-244. [CrossRef] 
8. Šustr, V.; Elhottová, D.; Krištůfek, V.; Lukešová, A.; Nováková, A.; Tajovský, K.; Tříska, J. Ecophysiology of the cave isopod Mesoniscus graniger (Frivaldsky, 1865) (Crustacea: Isopoda). Eur. J. Soil Biol. 2005, 41, 69-75. [CrossRef]

9. Crowther, T.W.; Stanton, D.W.; Thomas, S.M.; A'Bear, A.D.; Hiscox, J.; Jones, T.H.; Voriskova, J.; Baldrian, P.; Boddy, L. Topdown control of soil fungal community composition by a globally distributed keystone consumer. Ecology 2013, 94, 2518-2528. [CrossRef]

10. Ortiz, S.C.; Rohlfs, M. Isopod grazing induces down-regulation of Aspergillus nidulans anti-fungivore defence marker genes. Fungal Ecol. 2016, 20, 84-87. [CrossRef]

11. Kayang, H.; Sharma, G.D.; Mishra, R.R. Effect of an isopod grazing (Burmoniscus sp.) upon microbes and nutrient release from the decomposing leaf litter of Alnus nepalensis D. Don. Eur. J. Soil Biol. 1994, 30, 11-15.

12. Farkas, S.; Vilisics, F. A guide to the terrestrial isopods (Isopoda: Oniscidea) of Hungary. (Magyarország szárazföldi ászkarák faunájának határozója (Isopoda: Oniscidea). In Hungarian). Nat. Som. 2013, 23, 89-124.

13. Vona-Túri, D.; Szmatona-Túri, T.; Kiss, B. Terrestrial isopods (Crustacea: Isopoda: Oniscidea) on Hungarian highway margins. (Szárazföldi ászkarák együttesek (Crustacea: Isopoda: Oniscidea) a magyarországi autópályák szegélyzónájában. Természetvédelmi Közlemények 2013, 19, 106-116. (In Hungarian)

14. Karasawa, S.; Nakata, K. Invasion stages and potential distributions of seven exotic terrestrial isopods in Japan. BioRisk 2018, 13, 53-76. [CrossRef]

15. Csonka, D.; Halasy, K.; Szabo, P.; Mrak, P.; Štrus, J.; Hornung, E. Eco-morphological studies on pleopodal lungs and cuticle in Armadillidium species (Crustacea, Isopoda, Oniscidea). Arthropod Struct. Dev. 2013, 42, 229-235. [CrossRef]

16. Gregory, S. Woodlice and Waterlice (Isopoda: Oniscidea \& Asellota) in Britain and Ireland; Field Studies Council/Centre for Ecology \& Hydrology: Telford, UK, 2009; pp. 1-176.

17. Vittori, M.; Gantar, I. The origin of microscopic spheres on the exoskeleton of the woodlouse Porcellionides pruinosus (Crustacea: Isopoda) and their effect on its hydrophobicity. Arthropod Struct. Dev. 2020, 58, 100968. [CrossRef]

18. Sutton, S.L.; Hassall, M.; Willows, R.; Davis, R.C.; Grundy, A. Life histories of terrestrial isopods: A study of intra-and inter-specific variation. In Symposia of the Zoological Society of London; Cambridge University Press: Cambridge, UK, 1984; Volume 53, pp. 269-294.

19. Mycobank. The MycoBank Engine and Related Databases. 2021. Available online: http://www.mycobank.org (accessed on 21 August 2018).

20. Khokhar, I.; Haider, M.S.; Mukhtar, I.; Mushtaq, S. Biological control of Aspergillus niger, the cause of Black-rot disease of Allium cepa L. (onion), by Penicillium species. J. Agrobiol. 2012, 29, 23-28. [CrossRef]

21. Cairns, T.C.; Nai, C.; Meyer, V. How a fungus shapes biotechnology: 100 years of Aspergillus niger research. Fungal Biol. Biotechnol. 2018, 5, 1-14. [CrossRef] [PubMed]

22. Coleman, J.J. The Fusarium solani species complex: Ubiquitous pathogens of agricultural importance. Mol. Plant. Pathol. 2015, 17, 146-158. [CrossRef] [PubMed]

23. Abeysinghe, S. Biological control of Fusarium solani f. sp. phaseoli the causal agent of root rot of bean using Bacillus subtilis CA32 and Trichoderma harzianum RU01. Ruhuna J. Sci. 2007, 2, 82-88, ISSN 1800-279x..

24. Gupta, G.K.; Sharma, S.K.; Ramteke, R. Biology, Epidemiology and Management of the Pathogenic Fungus Macrophomina phaseolina (Tassi) Goid with Special Reference to Charcoal Rot of Soybean (Glycine max (L.) Merrill). J. Phytopathol. 2012, 160, 167-180. [CrossRef]

25. Coser, S.M.; Reddy, R.V.C.; Zhang, J.; Mueller, D.S.; Mengistu, A.; Wise, K.A.; Allen, T.W.; Singh, A.; Singh, A.K. Genetic Architecture of Charcoal Rot (Macrophomina phaseolina) Resistance in Soybean Revealed Using a Diverse Panel. Front. Plant. Sci. 2017, 8, 1626. [CrossRef]

26. Purdy, L.H. Sclerotinia sclerotiorum: History, diseases and symptomatology, host range, geographic distribution and impact. Am. Phytopathol. Soc. 1979, 69, 875-880. [CrossRef]

27. Boland, G.J.; Hall, R. Index of plant hosts of Sclerotinia sclerotiorum. Can. J. Plant. Pathol. 1994, 16, 93-108. [CrossRef]

28. Kamal, M.M.; Savocchia, S.; Lindbeck, K.D.; Ash, G. Biology and biocontrol of Sclerotinia sclerotiorum (Lib.) de Bary in oilseed Brassicas. Australas. Plant. Pathol. 2015, 45, 1-14. [CrossRef]

29. Zándoki, E.; Szôdi, S.; Turóczi, G. Mycelial compatibility of Sclerotinia sclerotiorum strains of different areas. Acta Phytopathol. et Èntomol. Hung. 2005, 40, 295-301. [CrossRef]

30. Gamliel, A.; Katan, J. Involvement of fluorescent pseudomonads and other microorganisms in increased growth response of plants in solarized soils. Phytopathology 1991, 81, 494-502. [CrossRef]

31. Xu, T.; Agrawal, A.; Abashin, M.; Chau, K.J.; Lezec, H.J. All-angle negative refraction and active flat lensing of ultraviolet light. Nature 2003, 497, 470-474. [CrossRef]

32. Hammer, Ø.; Harper, D.; Ryan, P. PAST: Paleontological statistics software package for education and data analysis. Palaeontol. Electron. 2001, 4, 4-9.

33. Zhang, W.; Ricketts, T.H.; Kremen, C.; Carney, K.; Swinton, S.M. Ecosystem services and dis-services to agriculture. Ecol. Econ. 2007, 64, 253-260. [CrossRef]

34. Sekercioglu, C.H. Ecosystem functions and services. In Conservation Biology for All, 1st ed.; Sodhi, N.S., Ehrlich, P.R., Eds.; Oxford University Press Inc.: New York, NY, USA, 2010; pp. 45-72. 
35. Kulmatiski, A.; Anderson-Smith, A.; Beard, K.; Doucette-Riise, S.; Mazzacavallo, M.; Nolan, N.E.; Ramirez, R.A.; Stevens, J.R. Most soil trophic guilds increase plant growth: A meta-analytical review. Oikos 2014, 123, 1409-1419. [CrossRef]

36. De Long, J.R.; Fry, E.L.; Veen, G.; Kardol, P. Why are plant-soil feedbacks so unpredictable, and what to do about it? Funct. Ecol. 2019, 33, 118-128. [CrossRef]

37. Rabatin, S.C.; Stinner, B.R. Arthropods as consumers of vesicular-arbuscular mycorrhizal fungi. Mycologia 1985, 77, 320-322. [CrossRef]

38. Smrž, J.; Kováč, L.; Mikeš, J.; Sustr, V.; Lukešová, A.; Tajovský, K.; Nováková, A.; Režňáková, P. Food sources of selected terrestrial cave arthropods. Subterr. Biol. 2015, 16, 37-46. [CrossRef]

39. Balázs, N. Microhabitat preference and plant pathogen consumption of terrestrial woodlice. (Szárazföldi ászkarákok mikrohabitat-preferenciájának és kórokozó-fogyasztásának vizsgálata). Master's Thesis, Szent István University, Gödöllő, Hungary; p. 104. (In Hungarian).

40. Zimmer, M. Nutrition in terrestrial isopods (Isopoda: Oniscidea): An evolutionary-ecological approach. Biol. Rev. 2002, 77, 455-493. [CrossRef] [PubMed]

41. Póss, A.; Plangár, N.; Turóczi, G.; Tóth, F. Susceptibility of terrestrial isopods as non-target organisms to the entomopathogenic fungi Beauveria bassiana and Metarhizium anisopliae in laboratory experiments (Szárazföldi ászkarákok mint nem-cél szervezetek érzékenysége Beauveria bassiana és Metarhizium anisopliae entomopatogén gombákra laboratóriumi kísérletben). Növényvédelem 2017, 78, 259-263. (In Hungarian)

42. Ihnen, K.; Zimmer, M. Selective consumption and digestion of litter microbes by Porcellio scaber (Isopoda: Oniscidea). Pedobiologia 2008, 51, 335-342. [CrossRef]

43. Gerlach, A.; Russell, D.J.; Jaeschke, B.; Römbke, J. Feeding preferences of native terrestrial isopod species (Oniscoidea, Isopoda) for native and introduced leaf litter. Appl. Soil Ecol. 2014, 83, 95-100. [CrossRef]

44. El-Wakeil, K.F.A. Effects of terrestrial isopods (Crustacea: Oniscidea) on leaf litter decomposition processes. J. Basic Appl. Zoöl. 2015, 69, 10-16. [CrossRef]

45. Abarca, M.L.; Bragulat, M.R.; Gastellá, G.; Cabañes, F.J. Ochratoxin A production by strains of Aspergillus niger var. niger. Appl. Environ. Microbiol. 1994, 60, 2650-2652. [CrossRef]

46. Kautz, G.; Zimmer, M.; Topp, W. Responses of the parthenogenetic isopod, Trichoniscus pusillus (Isopoda: Oniscidea), to changes in food quality. Pedobiologia 2000, 44, 75-85. [CrossRef]

47. Bhattacharya, D.; Dhar, T.K.; Siddiqui, K.A.I.; Ali, E. Inhibition of seed germination by Macrophomina phaseolina is related to phaseolinone production. J. Appl. Bacteriol. 1994, 77, 129-133. [CrossRef]

48. Huang, H.C.; Dorrell, D.G. Screening sunflower seedlings for resistance to toxic metabolites produced by sclerotinia sclerotiorum. Can. J. Plant. Sci. 1978, 58, 1107-1110. [CrossRef]

49. Forró, L.; Farkas, S. Checklist, preliminary distribution maps, and bibliography of woodlice in Hungary (Isopoda: Oniscidea). Misc. Zool. Hung. 1998, 12, 21-44.

50. Nair, A.; Ngouajio, M. Soil microbial biomass, functional microbial diversity, and nematode community structure as affected by cover crops and compost in an organic vegetable production system. Appl. Soil Ecol. 2012, 58, 45-55. [CrossRef]

51. Oka, Y. Mechanisms of nematode suppression by organic soil amendments-A review. Appl. Soil Ecol. 2010, 44, 101-115. [CrossRef]

52. Lupatini, M.; Korthals, G.W.; De Hollander, M.; Janssens, T.K.S.; Kuramae, E.E. Soil Microbiome Is More Heterogeneous in Organic Than in Conventional Farming System. Front. Microbiol. 2017, 7, 2064. [CrossRef]

53. Ghini, R.; Morandi, M.A.B. Biotic and abiotic factors associated with soil suppressiveness to Rhizoctonia solani. Sci. Agricola 2006, 63, 153-160. [CrossRef]

54. Huss, M.J. Dispersal of Cellular Slime Molds by two Soil Invertebrates. Mycologia 1989, 81, 677-682. [CrossRef]

55. Corvalan, C.; Hales, S.; McMichael, A. Ecosystems and Human Well-Being: Health Synthesis: A Report of the Millennium Eco-System Assessment; World Health Organization: Geneva, Swtizerland, 2005; pp. 1-53. 